\title{
Audit Structure, Time Pressure and Judgment Accuracy: A Comparison between Strategic System Audit and Traditional Audit
}

\author{
Murad Abuaddous ${ }^{1}$, Mustafa Mohd Hanefah ${ }^{1} \&$ Nur Hidayah Laili ${ }^{1}$ \\ ${ }^{1}$ Faculty of Economics and Muamalat, Universiti Sains Islam Malaysia (USIM), Malaysia \\ Correspondence: Murad Abuaddous, Faculty of Economics and Muamalat, Universiti Sains Islam Malaysia \\ (USIM), Malaysia. E-mail: addose.murad@ hotmail.com
}

Received: May 8, 2015

Accepted: May 22, 2015

Online Published: July 25, 2015

doi:10.5539/ijef.v7n8p53

URL: http://dx.doi.org/10.5539/ijef.v7n8p53

\begin{abstract}
The development of audit practice is a continuous process. The strategic system audit (SSA) method is a quite recent audit procedure that represents a complete shift from old audit techniques as it relies on assessing the client's business risk using a top-down rather than a bottom-up (traditional) approach. Previous studies focused on the effectiveness of SSA in performing audit. In addition, previous studies did not rule out the role of auditors' experience in an experimental procedure that compares between the two methods. Moreover, the effect of time pressure on auditors' "JDM" effectiveness under Traditional Audit (TA) and SSA during the orientation phase is still lacking in the literature. Using expert auditors as a benchmark and 81 master degree students, a2x2 factorial design experiment and a Mann-Whitney $U$ test show that auditors under SSA method issue a more effective audit assessment than under TA in the absence or presence of time pressure.
\end{abstract}

Keywords: strategic system audit, traditional audit, time pressure, business risk assessment, audit risk

\section{Introduction}

Business Risk Assessment (BRA) is the process of determining whether a particular uncertain circumstance has the potential to threaten one's business operations. Business risk is generally defined as the risk that an entity's business objective will not be attained as a result of external and internal factors, pressures, and forces brought to bear on the entity and is ultimately, the risk associated with the entity's survival and profitability (Bell et al., 1998). Business risks arise from conditions and forces within the organization's internal environment, industry forces and macro-environmental forces. An understanding of business risk widens the auditor's focus, from audit risk, defined with reference to financial statement error, to business risk, defined as the risk that an entity will fail to meet its objectives (Eilifsen et al., 2001; Higson, 1997). Business risk ultimately translates into the risk of financial statement error. Therefore, an approach which focuses on understanding a business, its environment and business processes provides the best means by which an auditor can recognize risks associated with management fraud and business failure (Erickson et al., 2000). This study focuses on BRA under two different audit structures: SSA and TA. Each method follows a unique mental model that aims to integrate the results of BRA to the audit risk model for the purpose of constructing an audit plan (also known as the orientation phase).

Previous studies argue that TA suffers from an absence of a clear structural process that helps the auditors to integrate the business risk evaluation into the audit risk model (Bell et al., 1998; Diaz, 2005; Kotchcova, 2002). Integrating the results of business risk evaluation into the audit process for TA occurs in conjunction with the analytical procedure process (O'Donell \& Myers, 2003) because of the bottom-up approach followed by this method. This late integration may reduce auditors' ability to include the evaluation of the business risk in the auditor's mental model. It also results in excluding important non-sampling information that may increase the risk of material misstatement (Peecher et al., 2007). Ketchcova et al. (2006) argues that the blurriness of TA structure in assessing the client's business risk will result in accuracy and validity reduction of audit risk assessment. Diaz (2005) provides further evidence on the difficult integration between BRA and the audit risk under TA method because auditor under TA relies solely on the standard recommendation (IAS 315, 2013 and SAS, 109) to understand the entity's environment and to assess the client's business risk without a clear integration in the audit risk model (Abdullatif \& Khadash, 2010).

In contrast, the most recognizable innovation that arrived with SSA adoption was the rigorous analysis of BRA for the audit client, with the intention of building a better integration between BRA and the risk of material 
misstatement. This view was shared by many researchers as they argued that BRA analysis under SSA is able to enhance auditors' cognitive knowledge and enable them to interact better with the client's complex system, in order to construct a more focused audit plan.

The process of understanding the client's business risk under SSA was established for the purpose of building a top-down, process-focused and holistic view of the client's environment (O'Donell \& Scultz, 2003; Lemon et al., 2000). This cognitive style is organized under a set of task structures that aim to focus auditors' attention on the related information of the client's system, decrease attention over irrelevant information, and reduce the complexity that surrounds the client's system. The outcome of BRA under SSA structure is expected to enhance auditors' understanding of the client's strategies and processes.

So far, few studies have tackled the issue of how SSA and TA method interact with BRA and audit risk assessment during the planning stage. Besides, no previous study has tested how these structures interact under the effect of time pressure to produce an audit judgment. This study aims to fill these gaps by constructing a $2 X 2$ laboratory experiment using 81 Master's degree students as "naïve users", who lacked knowledge of any previous decision-aid structure (Tortman et al., 2011). We investigate the judgment accuracy by matching the subjects' answers with those of an expert panel using a Mann-Whitney $U$ test to find which structure provides more effective audit judgment both in the absence and presence of time pressure. To answer our study questions, we relied upon the mental model theory and the cognitive style theory to predict how SSA and TA structure would behave in judgment decision making. We borrowed (Benson \& Beach, 1996; and Huber \& Kunz, 2007) model from the psychology field to control the level of time pressure as it provides a more flexible tool to manipulate the exact level of stress needed for the experiment. It is hypothesized that SSA structure is more able to increase auditors' judgment effectiveness than to TA. In addition, we hypothesize that time pressure has an inverse relation with auditors' judgment effectiveness, but that SSA can handle time pressure effect better than TA.

\subsection{Judgment Flow under TA}

Assessing the client's BRA under TA requires that the auditor conduct an informational search to understand the client's business risk and assess whether it indicates a risk of material misstatement that requires an adjustment of the audit risk model (Lemon et al., 2000). The process of assessing the risk of material misstatement under TA includes (1) collecting informational input such as (BRA, financial analysis, entity nature... etc.) about the audit client; then, (2) assessing the risk of this information; (3) and then documenting the expected output that may influence the audit risk model. Afterwards, the auditors are expected to (4) set the level of risk detection and proceed to analytical procedure (Eining et al., 1997; Bell et al., 1998; Messier, 2003).

During the analytical procedure, auditors search for inconsistency and fluctuations that may signal a risk of material misstatement. Two possible outcomes are expected: the first is that there is no indication of accounts' fluctuation, which indicates that auditors are confident about their judgment. The second possible outcome is the existence of a fluctuation in the client's account; under such scenario, the auditor develops a hypothesis that aims to explain the possible reason for the fluctuation occurrence (Koonce et al., 1993) (Note 1). If the hypothesis is proven to be correct, the auditor is then able to determine the acceptable level of detection risk and confirm the nature, timing, and extent of substantive procedures. Otherwise, there is need for a new hypothesis that requires further evidence search that involves a process of integrating other types of financial and non-financial evidence (e.g., business risk) in order to support the new hypothesis (Libby, 1985). This cycle will be repeated until the auditor finds a hypothesis that has the best explanation for the accounts' fluctuation.

\subsection{Mental Model for TA}

Johnson-Laird (1983) defines a mental model as an internally constructed process that represents a specific event based on the decision-maker's assumption combined with the decision-maker acquired knowledge. In audit literature, previous studies describe the TA structure as a transactional base search process that follows a bottom-up, linear thinking style to form a mental model about the client's system (Koonce et al., 1993; Libby \& Luft, 1993; O'Donnell, 2003; Choy \& King, 2005). The mental model is constructed through a "detail-type" cognitive thinking style structure that begins by diagnosing the problem that appears in the transactional level and goes on to search for a possible cause for these problems. This bottom-up cognitive thinking style retrieves the information by conducting a linear mental stimulation to explain the possible cause of the fluctuation (Klein, 1999). The auditor extends the informational input search and adds it to the primary assessment, in order to generate another hypothesis that aims to explain the fluctuation. In consequence, many studies expect a heavy load of informational input in the mental representation, which may disturb an effective integration of the BRA in the audit risk component and reduce the judgment consistency during the audit (Ketchova et al., 2006; 
O’Donnell \& Myser., 2003).

\subsection{Judgment Flow under SSA}

BRA under SSA structure undergoes a different process for audit than under TA. The planning stage preparation is more focused and oriented toward the client's BRA (Bell et al., 1998; Lemon et al., 2000; Knechel, 2001). It relies on an inductive, non-linear and complex feedback-loops thinking process that generates multiple complex mental models (O’Donnell \& Schultz, 2005). Each complex model covers a specific audit process that includes the results of strategic business assessment, the client's process/ sub process assessment, the business risk evaluation and the analytical procedure results. Together, they form a comprehensive view of the client's specific transaction details. Moreover, each single complex model is attached to other types of complex models that explain other audit processes. When combined, all the single mental models will lead to a complex comprehensive mental model that represents the client's system (Ballou \& Hetegier, 2005).

\subsection{Mental Model for SSA}

The mental model under SSA is constructed through a "global-type" cognitive thinking style structure that intends to build the auditor's perspective about the client's system from the top level of the organization and down to the transactional level (Humphrey et al., 2004). The process of assessing the risk of material misstatement under SSA begins by (1) analysing the strategic position of the audit client and then including the evaluation outcome in the mental model about potential risk of material misstatement in the account level. Peecher et al. (2007) argue that during the strategic analysis, the auditor collects evidence about the client's strategies, processes, economic factors and related past and current events in order to connect this information to the client's financial statement. Strategic analysis under SSA mainly focuses on collecting this information to integrate them into the specific strategy under scrutiny, and then assessing the risks that threaten the success of the strategy and their effect on the client's account (Bell et al., 2008). Afterwards, (2) auditors evaluate the client's process to understand how clients create values and to see whether the activities are showing an effective and efficient performance. The auditor is expected to build a comprehensive understanding of the client's business process risks in order to include the evaluation results in the mental model. For example, the following points should be covered by the auditors during the process analysis stage: (a) How the client creates value; $(b)$ Whether the client process is effectively aligned with the client's strategy; $(c)$ The level of process risks that threaten the business objectives; $(d)$ The process control effectiveness of risks; and $(e)$ The effectiveness of the identified core process activities and their related risks, and controls of the client's financial statement (Bell et al., 1998).

After completing the business risk evaluation under SSA structure, the auditors (3) integrate the results of risk assessment of the client's strategy and process within the residual risk analysis. According to Bell et al. (1998), the auditor develops an expectation about the key financial statement assertions and assesses the audit implications, including assertion or account level risk assessments and planning audit tests during the residual risk analysis. Thus, the integration of those 3 components is expected to provide a top-down holistic expectation of the client's financial statement that aims to compare this expectation with the client's operational and financial true position (Choy \& King, 2005). Together with the analytical procedure results, the mental representation should be able to explain fluctuation in the client's transactional details.

Finding an explanation for the client's account fluctuations under SSA is not based on hypothesis generation and testing as in TA; it rather involves comparing the auditors' expectation outcomes from the complex mental model with the actual results. If a variation between expectation and reality is found, the auditors need to perform additional information search to enhance the mental model. This cycle will be repeated until the auditor's expectations are met, or the client has to adjust to auditor's expectations.

So far, previous findings suggest that SSA leads to better audit judgment than TA. For example, Wright and Berger (2011) constructed an experiment to compare between the auditors' judgment in the presence or absence of chronological presentation of the client's strategic and process analysis. They found that auditors who performed a strategic analysis of the client's risks provide a better judgment. They also noted that using strategic analysis increases the valid usage of non-financial performance measures related to fraud risk. There results support Peecher's et al. (2007) argument that SSA increases attention over non-sampling risks. Knechel et al. (2012) found that strategic analysis provides a more balanced and accurate assessment of the client business risk. They provided further evidence that in-depth analysis of the client's strategy is able to enhance the integral mental model for the audit process. Kochetova and Messier (2011) argue that auditors who apply a strategic system analysis of the audit client are better able to produce a consistent judgment about the risk of material misstatement than those who do not use a strategic analysis. Moreover, they found that strategic analysis 
enhances judgment consistency when measuring the client's control environment. O'Donnell and Schultz (2003) investigated the effect of using different audit supports software in auditor's risk assessment in an experimental study that compared between auditors using a business process-focused and auditors using transaction cycle focus. The results indicate that auditors using business process-focused identified more risks than their counterparts. Bortiz et al. (2012) found that students who received a business process representation provided a better assessment of the organization business and control risks. Borthick et al. (2012) found that a graphical representation of business processes increases auditor's accuracy when assessing the audit risk for the client compared to the absence of such a tool. Ballou et al. (2012) argued that enhancing the process integration increases the ability to define the risks and the understanding of future events. O'Donnell and Schultz (2003) investigated the task complexity between the two audit methods and provided evidence that SSA is less complex than TA. Other studies showed that SSA improves auditor's judgments under a risky environment (O'Donnell \& Schultz, 2003; Schultz et al., 2010; Kotchetova et al., 2006), and enhances auditor's knowledge (O'Donnell, 2002; Kopp \& O'Donnell, 2005; Kotchetova et al., 2006). Risk evaluation under SSA has been reviewed in detail by many researchers such as Bruynseels et al. (2011) who investigated going concern issue by specialized auditors in the client industry. Eilifsen et al.'s (2001) practical experiment showed the effectiveness of risk evaluation under SSA. Furthermore, Bowlin (2008) investigated the auditor's sensitivity to fraud risk under SSA, and van Buuren (2014) showed how non-big audit uses more simple tools considered as hybrid tools between SSA and TA to evaluate the client risk.

In brief, we expect the effectiveness of the auditor's judgment to vary between SSA and TA, because SSA follows a global type cognitive thinking style that relies on a top-down holistic view over the client's system to form the mental model. In contrast, TA follows a "detail-type" cognitive thinking style that relies on a bottom-up view of the client's system to form the mental model. Moreover, each method uses a different technique to retrieve and integrate information. SSA uses an inductive, non-linear and complex feedback-loops thinking process to explain the client's fluctuation. TA follows a deductive and linear systematic thinking process that relies on generating multiple hypotheses to explain the fluctuation.

Therefore, in order to explore audit judgment effectiveness under both methods, we hypothesize the following:

\section{H1: Audit judgment effectiveness will increase under SSA structure compared that under TA structure in terms of BRA and audit risk component.}

The second objective in this paper is to explore the effect of time pressure on auditor's judgment. This relation tends to take a "U" shape, curvilinear-relation (known as Yerkes \& Dodson Law). However, audit studies indicate that this relation tends to have an inverse slope with the audit performance. This conflict was noted by Brown and King (2010) who argued that the level of stress is usually high in audit practise, which may explain these results.

McGarath (1976) argues that two factors are responsible for the amount of stress when performing a task: arousal and goal difficulty. Arousal is defined as the act of stimulating to readiness or to action, while goal difficulty is the amount of effort that the person performs to complete the task. A positive relationship was found between arousal and task performance (McGarath, 1976), but a negative relationship was found between goal difficulty and task performance (McGarath, 1976; Hirst \& Lowy, 1990; Lee et al., 1996; Webb et al., 2010). Researchers such as Scott (1966) argue that a low level of arousal negatively affects the task performance and vice-versa, while a high goal difficulty "such as limited time" even with high arousal can produce a form of stress for participants. As a result, goal difficulty is the dominant factor behind the negative relation.

There is a consensus in audit literature about a negative relation between time pressure and audit performance (McDaniel, 1990; Brown, 1999; Brown \& King, 2010; Low \& Tan, 2011). Evidence suggests that auditors' judgments are affected when dealing with risky or important decisions under the effect of time pressure, as they tend to choose less risky decisions than auditors with more available time (Ben Zur \& Breznitz, 1981; Diaz 2005). Correspondingly, Sevenson and Edland (1987) argue that auditors will tend to focus on the most critical areas of the client's account when time pressure is present. This explains Asare et al. (2000) findings that accountability for the decision is the auditors' main concern as they tend to minimize the extent and depth of the searching process but not the breadth of the test. Similarly, Miller (1960) suggests that people will cope with the effect of time pressure by filtering the information and choosing only the important one. Payne et al. (1996, p. 131) note that the stress from making choices under time pressure is 'often due not so much to strict deadlines as it is to the potential opportunity cost of delaying decisions'.

Overall, the negative relation between time pressure and audit performance overwhelmed other results in audit literature. We believe that the nature of the audit practice may contribute to this consensus as there is always an 
opportunity cost in audit practice that can result of any delay, especially during the engagement process (Naser et al., 2007; Arnold et al., 2000) and due to the fact that time pressure tends to be aggressive during the busy season (Marxen, 1990). Therefore, the level of goal difficulty is expected to be high because researchers will tend to mimic the harsh nature of the audit practice, which will lead to a negative effect of time pressure on auditors' performance no matter what the arousal level is.

In a similar fashion, audit structure also interacts with time pressure. Auditors under unstructured audit rely on identifying the problem, gathering the clues, searching for alternatives and then issuing an audit judgment (Sullivan, 1984; Keen \& Scott-Morton, 1978). Time pressure is expected to negatively influence the audit performance due to heavy reliance on the auditor's judgment (Brown, 1999; McDaniel, 1990; McGrath, 1976). On the other hand, auditors under structured task rely more on the qualitative analysis of the problem (Sullivan 1984). Therefore, they tend to rely more on information processing than on identifying problems (Bell et al., 1998; O’Donnell \& Schultz, 2003).

To this end, we assume that decisions under structured and unstructured task are not generated randomly; instead, auditors tend to change their techniques as a coping strategy to time pressure (McDaniel, 1990). These different interactions with time pressure under structured and unstructured audit will eventually lead to a variation in the judgment performance (Brown et al., 2010). However, a different adaptation technique will ultimately be subjected to the followed audit structure and its role in relaxing information processing and forming the audit judgment (Diaz, 2005; Brown, 1999; McDaniel, 1990). Therefore, it is expected that different audit structures will respond differently to time pressure. Given these facts, we expect that time pressure will result in different assessments of the client's business risk and audit risk assessment under a top-down thinking strategy compared to the bottom-up thinking strategy. To explore this relation, we hypothesize the following:

\section{H2a: As the level of time pressure increases, audit effectiveness will decrease.}

\section{H2b: Judgment effectiveness under SSA structure will exceed TA structure judgment effectiveness under time pressure.}

The rest of the study proceeds as follows: Material and methods, data analysis, study conclusion, and recommendations for future research.

\section{Material and Methods}

To test the effectiveness of the audit judgment, we rely upon a cognitive psychology theory as JDM is considered one branch of the theory. Cognitive style theory predicts that JDM varies depending on the thinking style. Jung (1923) attempted to describe how decision-makers perceive information for analysing two psychological functions: detail-types (a bottom-up processing) and global-types (a top-down processing). Hence, a guideline of a form of a top-down structural decision aid is expected to produce different judgments from a bottom-up structural decision aid. We also rely upon a mental model theory, as Libby and Lufft (1993) argue that auditors construct a mental model based on their knowledge combined with the acquired evidence. Auditors interpret the new information and audit evidence according to existing knowledge, in order to integrate this information within the overall picture in their mind about the audit client's system. A lot of audit studies detected that different adoptions of mental models lead to different effectiveness in audit judgment when auditors follow different audit structures, such as Boritz (1985), Butler (1985), Bamber and Snowball (1988), Bamber et al. (1989), Weber (1980), Libby and Frederick (1990), Bedard and Biggs (1991), Nelson (1993), Libby and Tan (1994), Choo and Tortman (1994), Peecher and Piercey (2008), Hmmersley (2006), and Earley et al. (2008). Although the term "mental model" was not specifically mentioned in some of these studies, yet there are strong indications that auditors' previous knowledge and newly acquired information from the proposed structure were integrated in an organized manner to produce audit judgment. Thus, the development of the mental model during the assessment of business risk is expected to vary between SSA and TA methods.

A factorial design experiment was conducted to test the study hypothesis. Koonce and Mercer (2005) and Tortman et al. (2011) encouraged audit researchers to use factorial analysis for behavioural auditing studies as it allows manipulating and controlling other variables in the same treatment. In a similar fashion, this study manipulates the audit structure and time pressure using a 2x2 factorial design in ANOVA to explore the study hypotheses.

The case material was based on the academic research literature (e.g., Abdolmohammadi \& Wright, 1987; Abdolmohammadi, 1999; Choy \& King, 2005; Eilifsen et al, 2001; Libby, 1985), the professional auditing standards (e.g., AICPA 2012, 2009), and textbooks (e.g., Lemon et al., 2000; Jung, 1923; Bell et al., 1998; Porter, 1980). Moreover, to examine the effect of time pressure, we relied upon two theories. The first is taken from 
McGarath, (1976) who argued that two factors are involved in subjecting task performance to a certain amount of stress: arousal and goal difficulty. The first is the arousal and goal difficulty theory which predicts that arousal and goal difficulty impact decision makers in an opposite direction: the more the experimentalist increases the arousal factor, the better the decision, and vice-versa. The second theory is the standard deviation theory formed by Benson and Beach (1996), who predict that deducting one standard deviation of the mean at a time will allow the experimentalist to accurately control the level of time pressure induced on the experiment subjects. Therefore, we deduct a 4 standard deviation from the pre-test results to induce the same level of time pressure that faces the auditors during their busy season.

Authentic data for the case material was taken from DAR-ALDAWA Company, which is considered as a leading firm in pharmaceutical industry in Jordan. The case material was sent to 4 professors and $6 \mathrm{Ph}$.D. holders who taught audit courses to comment on the clarity of the accounting and auditing terms that were used in the case material. A pilot study was conducted on $16 \mathrm{MA}$ students who were divided into two groups, each group contained 8 students who performed the case material under either SSA or TA, without any time limit. We then measured their completion time and calculated the standard deviation for them to induce our targeted time pressure for the actual study.

The study sample consisted of MA accounting or MBA students at Jordanian universities. To determine the number of subjects participating in the actual experiment, we relied on previous literature sampling. We analysed audit studies that used the experimental method design since the 1970s until to date to build our sample size based on the average number of participants they used. Table (1) summarizes these findings.

Table 1. Sample size adopted in previous studies

\begin{tabular}{ccc}
\hline The period & Number of Subject on average & Number of studies \\
\hline $\mathbf{1 9 7 0 - 1 9 7 9}$ & 68 & 11 \\
$\mathbf{1 9 8 0 - 1 9 8 9}$ & 71 & 30 \\
$\mathbf{1 9 9 0 - 1 9 9 9}$ & 89 & 55 \\
$\mathbf{2 0 0 0 -}$ Date & 95 & 53 \\
Average & $\mathbf{8 0 . 7 5}$ & $\mathbf{1 4 9}$ \\
\hline
\end{tabular}

The MA accounting or MBA in this study serve as "naive users" (Tortman et al., 2011), who can understand the general audit standards but do not anticipate any previous structures that may affect the test validity (Houghton \& Hronsky, 1993, p. 139; Mascha \& Miller, 2010), and who are capable of assessing semi-task structure (Abdolmohammadi \& Wright, 1987; Colbert, 1988; Chan et al., 2011). In addition, eight accounting professors supervised the experiment in order to achieve three main objectives: (1) To avoid group decision making; (2) To induce accountability by randomly asking the participants to explain their answers after their completion; (3) and to control the time pressure. Moreover, in order to determine the accuracy of the audit judgment, we send the case material to six senior auditors who were used as an experts' panel to measure the subjects' judgment effectiveness. This is a treatment adopted from Ketchcova (2002), who matches between the experts' answers and the subjects' answers by analysing the "Mean". We conduct this matching by analysing the "Median", using a Mann-Whitney U test as it is considered more appropriate for a smaller sample size (Sevin \& Schroeder, 2005; Abuaddous et al., 2014).

\section{Results}

As mentioned before, the first objective of this paper is to examine the audit judgment effectiveness under SSA structure compared to TA structure in terms of BRA and audit risk component. A 2x2 ANOVA test was carried out to find the effect of audit structure on BRA and audit risk components. Then, each structure findings compared to those of the expert panel to find which one reaches more effective assessment. Table (2) summarize our results. 
Table 2. Audit structure judgment effectiveness

\begin{tabular}{lccccc}
\hline & & & \multicolumn{2}{c}{ 2X2 ANOVA- SSA vs. TA } \\
\cline { 4 - 6 } & Type III Sum of Squares & Df & Mean Square & F & Sig \\
\hline Business Risk & 22.417 & 1 & 22.417 & 6.030 & .016 \\
Inherent Risk & 21.763 & 1 & 21.763 & 9.591 & .003 \\
Control Risk & 9.419 & 1 & 9.419 & 3.571 & .063 \\
Audit Risk & 26.335 & 1 & 23.004 & 9.364 & .003 \\
\hline & & & SSA compared to Expert Panel & Exact Sig \\
\cline { 3 - 6 } & Mann-Whitney U & Wilcoxon W & Z & Asymp. Sig. (2-tailed) & .096 \\
Business Risk & 72 & 975 & -1.768 & 0.077 & .493 \\
Inherent Risk & 103.5 & 1006.5 & -0.711 & 0.477 & .017 \\
Control Risk & 51.5 & 954.5 & -2.371 & .018 & .573 \\
Audit Risk & 107 & 1010 & -0.6 & .548 & \\
\hline & & & TA compared to Expert Panel & \\
\cline { 3 - 5 } & Mann-Whitney U & Wilcoxon W & Z & Asymp. Sig. (2-tailed) & .006 \\
\hline Business Risk & 37.5 & 817.5 & -2.79 & 0.005 & .034 \\
Inherent Risk & 54 & 834 & -2.122 & 0.034 & .006 \\
Control Risk & 38.5 & 818.5 & -2.675 & 0.007 & .049 \\
Audit Risk & 58.5 & 838.5 & -1.969 & 0.049 & \\
\hline
\end{tabular}

\subsection{Business Risk Assessment}

The $2 \times 2$ ANOVA results in Table 2 indicate a significant difference $(T=.016)$ between subjects who used the SSA structure to assess the client's business risk and those who followed the TA structure. Hence, the results indicate that audit under SSA significantly differs from that under TA. Judgment effectiveness was tested by Mann-Whitney U test to compare between the "Median" of assessments of each method and matched with that of the expert panel. Our results show a non-significant difference (Median= .096) between the expert panel's assessment and the study subjects' assessment under SSA method. In other words, the SSA participants' assessment was closer to the expert panel's assessment than that of TA participants. We found a significant difference (.006) between the expert panel's assessment and the TA subjects. This indicates that the assessments of the TA participants were less effective than those of the SSA subjects, which is consistent with our study hypotheses.

\subsection{Audit Risk Component}

Our results show a significant difference (.003) in assessing the client's inherent risk when participants used different audit methods. This supports the first hypothesis that BRA under different audit structures will eventually lead to different assessments of the audit risk component. The subjects' inherent risk assessment under both methods was matched with the expert panel's assessment. The "Median" analysis indicates that subjects who followed a top-down mental model had a better matching with the experts than those who followed a bottom-up mental model (Median= .493 and .034 , respectively). This result supports further that SSA leads to a more effective audit assessment of the inherent risk than TA.

In contrast to business assessment and inherent risk assessment results, we found an insignificant difference in the client's control risk assessment (.063) when we changed audit method. This indicates that the structural difference did not change the auditor's perspective of the client's control risk assessment. Moreover, the assessment under both methods did not show a significant matching with the expert panel's assessment (Median $=.017$ for SSA \& .006 for TA). In other words, neither method helped our subjects to produce an effective control risk assessment. We finally found a significant difference between the subject's assessments in the client's audit risk (.003) when auditors applied the SSA and TA methods structures. This result does not only support that using different structures leads to different assessments but also affects the accuracy of the judgment as we find that subjects' assessment under SSA structure better matched the experts' assessment (Median= .573), while subjects under TA provided a less effective judgment compared to that by the experts (Median= .049).

\subsection{Time Pressure vs. Audit Structure}

The second objective of this paper is to examine the effect of time pressure in auditors' judgment, as well as the structure which can achieve better assessment under such pressure. A 2x2 ANOVA test was conducted to find the effect of time pressure on BRA and audit risk components. Then each structure findings were compared to the 
expert panel's in order to find out which one reaches a more effective assessment. Table 3 summarizes our results.

Table 3. Time pressure judgment effectiveness

\begin{tabular}{|c|c|c|c|c|c|}
\hline & \multirow[b]{2}{*}{ Type III Sum of Squares } & \multirow[b]{2}{*}{ Df } & \multicolumn{2}{|c|}{ 2X2 ANOVA-Time Pressure effect } & \multirow[b]{2}{*}{ Sig } \\
\hline & & & Mean Square & $\mathrm{F}$ & \\
\hline Business Risk & 22.417 & 1 & 22.417 & 11.798 & .001 \\
\hline Inherent Risk & 15.037 & 1 & 15.037 & 6.627 & .012 \\
\hline Control Risk & 5.732 & 1 & 5.732 & 2.172 & .145 \\
\hline \multirow[t]{3}{*}{ Audit Risk } & 26.355 & 1 & 26.355 & 10.728 & .002 \\
\hline & & \multicolumn{4}{|c|}{ SSA compared to Expert Panel under Time Pressure } \\
\hline & Mann-Whitney U & Wilcoxon W & $\mathrm{Z}$ & Asymp. Sig. (2-tailed) & Exact Sig \\
\hline Business Risk & 21 & 231 & -2.499 & .012 & .016 \\
\hline Inherent Risk & 44 & 254 & -.990 & .322 & .355 \\
\hline Control Risk & 24.5 & 234.5 & -2.187 & .029 & .028 \\
\hline \multirow[t]{3}{*}{ Audit Risk } & 32 & 242 & -1.740 & .082 & .95 \\
\hline & & \multicolumn{4}{|c|}{ TA compared to Expert Panel under Time Pressure } \\
\hline & Mann-Whitney U & Wilcoxon W & $\mathrm{Z}$ & Asymp. Sig. (2-tailed) & Exact Sig \\
\hline Business Risk & 11 & 221 & -3.059 & .002 & .001 \\
\hline Inherent Risk & 21.5 & 231.5 & -2.358 & .018 & .016 \\
\hline Control Risk & 20 & 230 & -2.455 & .014 & .013 \\
\hline Audit Risk & 28 & 238 & -1.970 & .049 & .054 \\
\hline
\end{tabular}

\subsection{Business Risk Assessment}

The results indicate that inducing time pressure can significantly affect auditors' performance when assessing the client's business risk (.001). Accordingly, we conducted a Mann-Whitney $\mathrm{U}$ analysis in order to compare between subjects who perform under or without time pressure and the experts' panel. Our results show that auditors who performed without time pressure showed an insignificant difference compared with the expert panel (.15), while auditors who performed under such a stress scored a significant difference compared with the expert panel (.002). In other words, time pressure has a negative effect on auditors' assessment of business risk. With this in mind, we compared between the assessment of business risk under SSA structure and under TA structure to find out which method is less affected by time pressure. Our results showed that subjects under SSA were better able to produce an effective audit judgment (.016) when compared to those using TA (.001). However, neither method achieved a high level of judgment effectiveness under time pressure.

\subsection{Audit Risk Components}

Our results show a significant difference (.012) in auditors' assessment of the client's inherent risk when participants were subjected to time pressure effect. This difference has also been analysed using the "Median" with the intention of detecting the effectiveness of the inherent risk assessment in the absence or presence of time pressure. The results indicate that time pressure reduces audit assessment effectiveness (.075) when compared to normal conditions (0.34). Moreover, inherent risk assessment under SSA showed a better matching with that of the experts (.355) than under TA (.016). In addition, control risk was affected (.145) by time pressure in a less significant way when compared to risk in normal conditions. This indicates that time pressure did not significantly affect subjects' assessment of the control risk. We also conducted the "Median" test in order to match both groups' with the experts' assessment to find out under which condition the subjects issue a more effective assessment. However, contrary to our expectations, the accuracy of the client's control assessment was not significantly affected by time pressure, as neither group matched the expert panel in a significant way (.011). Lastly, the overall assessment of the client's audit risk shows a significant difference between subjects who performed under time pressure and those who did not (.002). Similar to our first hypothesis results, the audit risk assessment was significantly affected. Therefore, we argue that the significant variation between BRA and inherent risk assessment contributes to this significant difference. Likewise, we matched the experts' with the subjects' assessment of the audit risk using the Mann-Whitney U test. The results indicate that time pressure negatively affects auditors' accuracy (.051) when compared to normal conditions (.586). Moreover, audit risk assessment under SSA showed a better matching with the experts' (.095) than under TA in the presence of time 
pressure (.054).

\section{Discussion}

We expected that SSA structure regarding audit risk components is better able to enhance judgment effectiveness than TA structure. Our results confirm that SSA structure for BRA provides a better match to experts than TA structure and increases auditor's sensitivity towards audit risk components. Similar results were found in Ketchkova (2002), who shows that SSA improves the auditor's accuracy when assessing the client's risk. She also indicates that SSA provides a better linkage for audit provision, and that the assessment of misleading statements increases the likelihood that auditors will detect and recognize conditions associated with inconsistent fluctuations. Bell et al. (1997) and Lemon et al. (2000) suggest that auditors under SSA gather information about the client's business risk and integrate the obtained knowledge with fluctuations from the analytical procedure. They also argue that the integrations help the auditor to focus his/her effort on the suspected areas of material misstatement, which reduces the auditor's effort regarding the substantive test. Overall, these findings are consistent with ours, but we extended the research by combining the SSA procedure for the orientation phase with Abdullmohamadi's (1999) audit task structure to direct our study towards the total effect of using the SSA method and then compare it to TA. Ketchkova (2002) separated the SSA process into two processes (strategic content and strategic process) in order to investigate the effect of each process on auditor's assessment during the orientation phase. In a different scenario, our study finds similar results by solely measuring the difference between the two methods (SSA and TA) and by using different measurement tools to test the effectiveness of auditors' judgment when compared to that of the expert panel. More precisely, we used the "Medians" between the assessment of expert panel and the subjects we targeted by using a Mann-Whitney $U$ test that is able to compare between smaller sample sizes rather than the "mean" tests.

Auditors' JDMs under SSA method have also been investigated in this study. Choy and King (2005) presented a System Mediated Mental Model into provide an insight to how systems' thinking can lead to improve the decision-making process. His results show that those who apply a top-down approach as in SSA are better able to reduce systematic errors than auditors who apply a bottom-up approach that follows the (GAAP). Kotchetova et al. (2006) support these findings in four experiments that aimed to evaluate the influence of BRA on audit planning decision. O'Donnell et al. (2003) also found that the top-down approach and process-focused task structure increase auditors' ability to integrate evidence about risk factors while assessing misstatement risks. This result supports the claim that SSA approach improves audit performance by increasing the auditors' sensitivity to factors that increase the risk of misstatement. Our results are consistent with these findings as we replicated a top-down audit approach from Ketchcova (2002), Bell et al. (1997), and O'Donnell et al. (2003). We enhanced these models by controlling the experience factor from the mental model (see Libby \& Lufft, 1993) and focusing only on the auditors' acquired information. This procedure aimed to test the effect of the systematic median tools provided by both methods, as in O'Donnell et al. (2003), but without the distraction that may result from previous auditors' experience (Ketchcova, 2002).

The results of this study also showed that time pressure, which is considered as one form of stress, has a negative impact on auditors' JDM. The assessment of the client's business risk, inherent risk and audit risk showed that time pressure is an important factor to be recognized during the audit process, especially in terms of audit quality. Therefore, we argue that audit firms need to consider this factor in case of questioning audit quality. Another important finding is the different impact of time pressure on audit structure. We found that auditors' performance under SSA was negatively impacted by time pressure; however, it had more negative impact on TA auditors. Thus, we argue that even under stress, SSA allowed better performance than TA.

Previous studies focused mainly on the effect of time pressure during JDM. There was a general consensus about a negative effect of time pressure on JDM (Peterson \& Maher, 1976; Anderson, 1976; Schuler, 1980; Ben Zur \& Breznitz, 1981; Choo, 1986; McDaniel, 1990; Glover, 1997; Brown, 1999; Asare et al., 2000; Tortman et al., 2011). Our study findings did not shift from this trend. However, we included more sub-factors in the experiment for more accurate results as follows: first, we set time pressure using a clearer tool from phycology. Second, we mimicked the exact level of time pressure that auditors encounter during the audit implementation by conducting a small survey that targeted auditors' partners, to measure the level of time pressure the auditors face during the audit. Third, we selected a sample of inexperienced MA students to control the auditors' experience factor, as this factor was neglected in previous studies, such as (McDaniel, 1990; Brown, 1999; Ketchcova, 2002). Another important result of this study is the effectiveness of JDM under time pressure when auditors adopted different audit method. Very little data about the effect of time pressure under different structural tasks are available. The only notable study that handled this issue was Brown (1999), who found insignificant change in performance between highly structured and semi-structured tasks. Thus, our finding that SSA structure actually resulted in 
better performance under time pressure compared to TA is considered as a significant contribution in this field. Moreover, we kept for each methods its uniqueness by controlling the level of time pressure for both methods and not focusing on time itself. Each method was subjected to different time to complete the case, but both were under the same level of time pressure. This treatment was not adopted in previous studies, and it is hoped that it will be used in future studies, because it offers more flexible solutions in experimental design studies. Our results enhance those of Brown (1999) and McDaniel (1990), as we found that even under semi-structured audit, time pressure results in different performance.

\section{Summary and Recommendations}

To sum up, we can say that the present study has come up with several results. First, we find that auditors under the SSA audit method are able to provide better assessment of client's business risk, inherent risk and audit risk than auditors working under the TA method. These results support previous findings such as Lemon et al. (2000), Kotchetova (2002), Kotchetova et al. (2006), Knechel et al. (2012), and O’Donnell (2002). However, we controlled the experience factor in order to remove any previous mental model or systematic thinking tool that the auditors may have used in previous working experience in order to assess our case material. We improved Ketchkova (2002) findings by eliminating one major limitation in her study. Our method also conform to methods by previous studies such as Liyanarachi (2007), Mortensen et al. (2012), Colbert (1988), Abdolmohammadi and Wright (1987), Houghton and Hronsky (1993, p. 139) that support using MA students as surrogates to experts. This opens the door for further research in behavioural accounting studies within this trend. Second, we find that time pressure when completing the audit task affects audit (JDM) effectiveness. Thus, audit quality decreases when the audit firms put their staff on a limited time budget to complete the audit process. However, we find that time pressure affects the quality of the audit under SSA method by a lower degree than under TA. In other words, the top-down methods can resist the effect of time pressure in a better way than the bottom-up audit one. The reason for these results may be consistent with Ballou (2001) and O'Donnell (2002), in that the mental model and the systematic thinking organization for the SSA method enhance the built-up knowledge and the retrieving process in auditors' minds. Therefore, we suggest that audit firms should consider using the top-down method to improve audit quality. Finally, we have included a new method borrowed from psychology to induce time pressure effect and found results similar to those of other studies (McDaniel, 1990; Glover, 1997; Brown, 1999; Arnold et al., 2000; Brown \& King, 2010; low and Tan, 2011; Lee, 2012; and Robinson, 2011) that use a different method to induce time pressure. Hence, we have enhanced behavioural audit studies by introducing a new method that is able to determine a specific amount of time pressure for the subjects and avoid the U-shape effect in laboratory experimental studies.

Our study has contributed to audit research literature in several ways. First, it shed light on how different audit structures respond to time pressure in the audit task. Second, it combined psychology with accounting theories by examining whether the audit structure is able to affect the auditor's cognitive ability in the absence of previous professional experience. Third, it contributed to the relatively scarce experimental research in the auditing literature regarding this topic. Future studies can focus on enhancing the effect of auditor's experience by increasing the study sample to include different levels of experienced auditors, to investigate which method is able to improve the auditor's JDM in the long run. Other studies can use our time pressure model to find the optimal point of time pressure in the U-shape relation that could increase auditor's performance and help audit firms to set their time budget and improve audit quality. In addition, researchers can investigate which method can provide more customer satisfaction, especially in a high-risk political environment, such as the Middle East, or in a highly risky natural environment such as South East Asia.

\section{References}

Abdolmohammadi, M. J. (1999). A comprehensive taxonomy of audit task structure, professional rank and decision aids for behavioral research. Behavioral Research in Accounting, 11, 51-92. Retrieved from http://search.proquest.com/docview/203299937? accountid=33993

Abdolmohammadi, M., \& Wright, A. (1987). An examination of the effects of experience and task complexity on audit judgments. The Accounting Review, 62(1), 1. Retrieved from http://search.proquest.com/docview/218574006? accountid=33993

Abdullatif, M., \& Al-Khadash, H. (2010). Putting audit approaches in context: The case of business risk audits in jordan. International Journal of Auditing, 14(1), 1-24. http://dx.doi.org/10.1111/j.1099-1123.2009.00400.x

Abuaddous, M., Hanefah, M. M., \& Laili, N. H. (2014). Accounting standards, goodwill impairment and earnings management in Malaysia. International Journal of Economics and Finance, 6(12), 201-211. http://dx.doi.org/10.5539/ijef.v6n12p201 
Arnold, V., Sutton, S. G., Hayne, S. C., \& Smith, C. A. P. (2000). Group decision making: The impact of opportunity-cost time pressure and group support systems. Behavioral Research in Accounting, 12, 69-96. Retrieved from http://search.proquest.com/docview/203297438?accountid=33993

Asare, S. K., Trompeter, G. M., \& Wright, A. M. (2000). The effect of accountability and time budgets on auditors' testing strategies. Contemporary Accounting Research, 17(4), 539-560. http://dx.doi.org/10.1506/F1EG-9EJG-DJ0B-JD32

Ballou, B., \& Heitger, D. L. (2005). A cognitive characterization of audit analytical procedures under strategic-systems auditing. The Journal of Theoretical Accounting Research, 1(1), 1-37. Retrieved from http://search.proquest.com/docview/195098999?accountid=33993

Ballou, B., Casey, R. J., Grenier, J. H., \& Heitger, D. L. (2012). Exploring the strategic integration of sustainability initiatives: Opportunities for accounting research. Accounting Horizons, 26(2), 265-288. http://dx.doi.org/10.2308/acch-50088

Bamber, E. M., Bamber, L. S., \& Bylinski, J. H. (1988). A descriptive study of audit managers' working paper review. Auditing: A Journal of Practice \& Theory, 7(2), 137-149. Retrieved from http://digital.library.unt.edu/ark:/67531/metadc103383/

Bamber, E. M., Snowball, D., \& Tubbs, R. M. (1989). Audit structure and its relation to role conflict and role ambiguity: An empirical investigation. The Accounting Review, 64(April), 285-299. Retrieved from http://www.jstor.org/stable/248003

Bedard, J., \& Biggs, S. (1989). Processes of Pattern Recognition and Hypothesis Generation in Analytical Review. Working paper, University of Connecticut. Retrieved from http://accounting.business.uconn.edu/wpcontent/uploads/sites/722/2014/11/BiggsVita2010.pdf

Bell, T. B., Doogar, R., \& Solomon, I. (2008). Audit labor usage and fees under business risk auditing. Journal of Accounting Research, 46(4), 729-760. http://dx.doi.org/10.1111/j.1475-679X.2008.00291.x

Bell, T. B., Knechel, W. R., Payne, J. L., \& Willingham, J. J. (1998). An empirical investigation of the relationship between the computerization of accounting systems and the incidence and size of audit differences. Auditing, 17(1), 13-38. $\quad$ Retrieved from http://search.proquest.com/docview/216733465?accountid=33993

Bell, T. B., Marrs, F. O., Solomon, I., Howard, T., \& Rao, H. (1999). Book review: Auditing organizations through a strategic-systems lens: The KPMG business measurement process. The CPA Journal, 69(7), 53-55. Retrieved from http://search.proquest.com/docview/212304280?accountid=33993

Ben Zur, H., \& Breznitz, S. J. (1981). The effect of time pressure on risky choice behavior. Acta Psychologica, 47, 89-104. http://dx.doi.org/10.1016/0001-6918(81)90001-9

Benson, L., \& Beach, L. R. (1996). The effects of time constraints on the pre-choice screening of decision options. Organizational Behavior and Human Decision Processes, 67, 222-228. http://dx.doi.org/10.1006/obhd.1996.0075

Boritz, J. E., Borthick, A. F., \& Presslee, A. (2012). The effect of business process representation type on assessment of business and control risks: Diagrams versus narratives. Issues in Accounting Education, 27(4), 895-915. http://dx.doi.org/10.2308/iace-50144

Borthick, A. F., Schneider, G. P., \& Vance, A. (2012). Using graphical representations of business processes in evaluating internal control. Issues in Accounting Education, 27(1), 123-140. http://dx.doi.org/10.2308/iace-50078

Bowlin, K. O. (2008). Can strategic reasoning prompts improve auditors' sensitivity to fraud risk? (Order No. 3320660). Available from ProQuest Central; ProQuest Dissertations \& Theses Global. Retrieved from http://search.proquest.com/docview/304482340?accountid=33993

Bowrin, A. R. (1999). Time pressure, task structure, and audit effectiveness (Order No. 9982040). Available from ProQuest Central; ProQuest Dissertations \& Theses Global. http://dx.doi.org/10.1108/02686901011008963

Bowrin, A. R., \& King, J. II. (2010). Time pressure, task complexity, and audit effectiveness. Managerial Auditing Journal, 25(2), 160-181. http://dx.doi.org/10.1108/02686901011008963

Bruynseels, L., Knechel, W. R., \& Willekens, M. (2011). Auditor differentiation, mitigating management actions, and audit-reporting accuracy for distressed firms. Auditing, 30(1), 1-20. http://dx.doi.org/10.2308/aud.2011.30.1.1 
Butler, S. A. (1985). Application of a decision aid in the judgmental evaluation of substantive test of details samples. Journal of Accounting Research (Autumn), 513-526. Retrived from http://www.jstor.org/stable/2490824

Chan, C., Landry, S. P., \& Troy, C. (2011). Examining External Validity Criticisms in the Choice of Students as subject in accounting experiment studies. Journal of Theoretical Accounting Research, 7(1). Retrieved from http://jtar.org/id5.html

Choo, \& Tortman. (1991). The relationship between knowledge structure and judgment for experienced and inexperienced auditors. The Accounting Review, 66(3), 315-330.

Choy, A. K., \& King, R. R. (2005). An experimental investigation of approaches to audit decision making: An evaluation using systems-mediated mental models. Contemporary Accounting Research, 22(2), 311-350. http://dx.doi.org/10.1506/U1HA-WNBV-URDB-E5P1

Colbert, J. L. (1988). Inherent risk: An investigation of auditors' judgments. Accounting, Organizations and Society, 13(2), 111. http://dx.doi.org/10.1016/0361-3682(88)90039-6

Diaz, M. C. (2005). Risk identification and assessment in a risk based audit environment: The effects of budget constraints and decision aid use (Order No. 3231520). ProQuest Dissertations \& Theses Global. (305372192). Retrieved from http://search.proquest.com/docview/305372192? accountid=33993

Earley, C., Hoffman, V., \& Joe, J. (2008). Reducing management's influence on auditors' judgments: An experimental investigation of SOX 404 assessments. The Accounting Review, 83(6), 1461-1485. http://dx.doi.org/10.2139/ssrn.1304292

Eilifsen, A., Knechel, W. R., \& Wallage, P. (2001). Application of the business risk audit model: A field study. Accounting Horizons, 15(3), 193-207. http://dx.doi.org/10.2308/acch.2001.15.3.193

Eining, M. M., Jones, D. R., \& Loebbecke, J. K. (1997). Reliance on decision aids: An examination of auditors' assessment of management fraud. Auditing, 16(2), 1-19. Retrieved from http://search.proquest.com/docview/216740570?accountid=33993

Erickson, M., Mayhew, B. W., \& Felix, Jr. W. L. (2000). Why do audits fail? Evidence from Lincoln Savings and Loan. Journal of Accounting Research, 38(Spring), 165-194. http://dx.doi.org/10.2307/2672927

Glover, S. M. (1997). The influence of time pressure and accountability on auditors' processing of nondiagnostic information. Journal of Accounting Research, 35(2), 213-226. http://dx.doi.org/10.2307/2491361

Higson, A. (1997). Time to bridge the expectations gap. Accountancy, 120(1249), 76. Retrieved from http://search.proquest.com/docview/217631566?accountid=33993

Hirst, M. K., \& Lowy, S. M. (1990). The linear additive and interactive effects of budgetary goal difficulty and feedback on performance. Accounting, Organizations and Society, 15(5), 425. http://dx.doi.org/10.1016/0361-3682(90)90026-Q

Houghton, K. A., \& Hronsky, J. J. F. (1993). The sharing of meaning between accounting students and members of the accounting profession. Accounting and Finance, 33(2), 131. http://dx.doi.org/10.1111/j.1467-629X.1993.tb00324.x

Huber, O., \& Kunz, U. (2007). Time pressure in risky decision-making: Effect on risk defusing. Psychology Science, 49(4), 415-426. Retrieved from http://search.proquest.com/docview/212205466? accountid=33993

Humphrey, C., Jones, J., Rihab, K., \& Keith, R. (2004). Business Risk Auditing and the Auditing Profession: Status, Identity and Fragmentation. Working Paper. Retrieved from http://www.lse.ac.uk/accounting/CARR/events/previousConferencesWorkshops/auditingPresentations/hum phrey.pdf

Jacqueline, S. (2006). Pattern Identification and Industry-Specialist Auditors. The Accounting Review, 81(2), 309-336. http://dx.doi.org/10.2308/accr.2006.81.2.309

Johnson-Laird, P. N. (1983). Mental Models: Towards a Cognitive Science of Language, Inference, and Consciousness. Cambridge: Cambridge University Press. Retrieved from http://www.jstor.org/stable/414498

Jung, C. G. (1923). Psychological types. New York: Random House. Retrieved from http://www.wiley.com/college/westen/0471387541/

Keen, P. G. W., \& Scott Morton, M. S. (1978). Decision support systems: An organizational perspective. Mass: Addison-Wesley Pub. 
Kin-Yew, L., \& Hun-Tong, T. (2011). Does Time Constraint Lead to Poorer Audit Performance? Effects of Forewarning of Impending Time Constraints and Instructions. Auditing: A Journal of Practice \& Theory, 30(4), 173-219. http://dx.doi.org/10.2308/ajpt-10180

Klein, G. (1999). Sources of power: How people make decisions. Personnel Psychology, 52(2), 515-518. Retrieved from http://search.proquest.com/docview/220139560?accountid=33993

Knechel, W. R. (2001). Auditing, Assurance \& Risk, South-Western (2nd ed.).

Knechel, W. R., Sharma, D. S., \& Sharma, V. D. (2012). Non-audit services and knowledge spillovers: Evidence from New Zealand. Journal of Business Finance \& Accounting, 39(1-2), 60. http://dx.doi.org/10.1111/j.1468-5957.2011.02268.x

Kochetova-Kozloski, N., \& Messier, W. F. Jr. (2011). Strategic analysis and auditor risk judgments. Auditing, 30(4), 149-171. http://dx.doi.org/10.2308/ajpt-10147

Kochetova-Kozloski, N., \& Messier, William, F. Jr. (2011). Strategic Analysis and Auditor Risk Judgments. Auditing, 30(4), 149-171. http://dx.doi.org/10.2308/ajpt-10147

Koonce, L., Walker, N. R., \& Wright, W. F. (1993). A cognitive characterization of audit analytical review; $\begin{array}{lllll}\text { Discussion. } & \text { Auditing, } & \text { 12, } & \text { Retrieved } & \text { from }\end{array}$ http://search.proquest.com/docview/216734168?accountid=33993

Kopp, L. S., \& O’Donnell, E. (2005). The influence of a business-process focus on category knowledge and internal control evaluation. Accounting, Organizations and Society, 30(5), 423-434. http://dx.doi.org/10.1016/j.aos.2004.03.004

Kotchetova, N. V. (2002). An analysis of client's strategy content and strategy process: Impact on risk assessment and audit planning (Order No. 3073674). ProQuest Central; ProQuest Dissertations \& Theses Global. Retrieved from http://search.proquest.com/docview/305581249?accountid=33993

Kotchetova, N., Ed O'Donnell, \& Webb, A. (2006). The Influence of Business Risk Assessments on Audit Planning Decisions: A Descriptive Model with Experimental Evidence (Unpublished paper).

Lee, D. S. (1996). Auditor market share, product differentiation and audit fees. Accounting and Business Research, 26(4), 315. http://dx.doi.org/10.1080/00014788.1996.9729521

Lee, H. (2012). Incentive contracts and time pressure on audit judgment performance. Managerial Auditing Journal, 27(3), 263-283. http://dx.doi.org/10.1108/02686901211207492

Lemon, W. M., Tatum, K. W., \& Turley, W. S. (2000). Developments in the Audit Methodologies of Large Accounting Firms. London: ABG Publications. Retrieved from http://trove.nla.gov.au/version/44499276

Libby, R. (1985). Availability and the generation of hypotheses in analytical review. Journal of Accounting Research, 23(2), 648. http://dx.doi.org/10.2307/2490831

Libby, R., \& Luft, J. (1993). Determinants of judgment performance in accounting settings: Ability, knowledge, motivation, and environment. Accounting, Organizations and Society, 18(5), 425. http://dx.doi.org/10.1016/0361-3682(93)90040-D

Libby, R., \& Tan, H. (1994). The Determinants of Auditor Expertise. Accounting, Organizations and Society, 19(8), 710-716. http://dx.doi.org/10.1016/0361-3682(94)90030-2

Liyanarachchi, G. A. (2007). Feasibility of using student subjects in accounting experiments: A review. Pacific Accounting Review, 19(1), 47-67. http://dx.doi.org/10.1108/01140580710754647

Marxen, D. E. (1990). A behavioral investigation of time budget preparation in a competitive audit environment. $\begin{array}{lllll}\text { Accounting Horizons, } & 4(2), & \text { Retrieved } & \text { from }\end{array}$ http://search.proquest.com/docview/208907966?accountid=33993

Mascha, M. F., \& Cathleen, L. M. (2010). The Effects of Task Complexity, Skill, and Work Program Use on Over-Underestimation of Internal Control. Managerial Auditing Journal, 25(8).

McDaniel, L. S. (1990). The Effects of Time Pressure and Audit Program Structure on Audit Performance. Journal of Accounting Research, 28, 267-281. http://dx.doi.org/10.2307/2491150

McGrath, J. E. (1976). Stress and behaviour in organizations. In M. D. Dunnette (Ed.), Handbook of industrial and organizational psychology (pp. 1351-1395). Chicago, IL: Rand McNally College Publishing Company http://dx.doi.org/10.1002/9780470774755.refs 
Messier, W. F. Jr. (2003). Auditing and Assurance Services: A Systematic Approach. The McGraw-Hill Companies, Inc.

Miller, J. G. (1960). Information input overload and psychopathology. American Journal of Psychiatry, 116, 695-704. http://dx.doi.org/10.1176/ajp.116.8.695

Mortensen, T., Fisher, R., \& Wines, G. (2012). Students as surrogates for practicing accountants: Further evidence. Accounting Forum, 36(4), 251. http://dx.doi.org/10.1016/j.accfor.2012.06.003

Naser, K., Abdulhameed, H., \& Nuseibeh, R. (2007). Determinants of Audit Fess: Empirical Evidence from Emerging Economy. Scientific Journal of Administrative Development, 5, 84-116. http://dx.doi.org/10.1108/10569210710833635

Nelson, M. W. (1993). The effects of error frequency and accounting knowledge on error diagnosis. The Accounting Review, 68(October), 804-824. Retrieved from http://www.jstor.org/stable/248505

O'Donnell, E. (2002). Evidence of an association between error-specific experience and auditor performance during analytical procedures. Behavioral Research in Accounting, 14, 179-195. http://dx.doi.org/10.2308/bria.2002.14.1.179

O’Donnell, E., \& Myers, P. M. (2003). Evidence of a link between decision strategy selection and auditor performance during analytical procedures. Academy of Accounting and Financial Studies Journal, 7(2), 43-56. Retrieved from http://search.proquest.com/docview/213980513?accountid=33993

O'Donnell, E., \& Schultz, J. J. Jr. (2003). The influence of business-process-focused audit support software on analytical procedures judgments. Auditing, 22(2), 265-295. http://dx.doi.org/10.2308/aud.2003.22.2.265

O’Donnell, E., \& Schultz, J. J. Jr. (2005). The halo effect in business risk audits: Can strategic risk assessment bias auditor judgment about accounting details? The Accounting Review, 80(3), 921-939. Retrieved from http://search.proquest.com/docview/218543783? accountid=33993

Payne, D. G., Elie, C. J., Blackwell, J. M., \& Neuschatz, J. S. (1996). Memory illusions: Recalling, recognizing, and recollecting events that never occurred. Journal of Memory and Language, 35(2), 261. http://dx.doi.org/10.1006/jmla.1996.0015

Peecher, \& Piercey (2008). Judging Audit Quality in Light of Adverse Outcomes: Evidence of Outcome Bias and Reverse Outcome Bias. Contemporary Accounting Research, 25(1), 243-274. http://dx.doi.org/10.1506/car.25.1.10

Peecher, M. E., Schwartz, R., \& Solomon, I. (2007). It's all about audit quality: Perspectives on strategic-systems auditing. Accounting, Organizations and Society, 32(4), 463. http://dx.doi.org/10.1016/j.aos.2006.09.001

Porter, M. E. (1980). Competitive Strategy. New York: Free Press.

Robinson, S. N. (2011). An experimental examination of the effects of goal framing and time pressure on auditors' professional skepticism (Order No. 3529253). ProQuest Dissertations \& Theses Global. Retrieved from http://search.proquest.com/docview/1041248324? accountid=33993

Schultz, J. J., Jr, Bierstaker, J. L., \& O’Donnell, E. (2010). Integrating business risk into auditor judgment about the risk of material misstatement: The influence of a strategic-systems-audit approach. Accounting, Organizations and Society, 35(2), 238. http://dx.doi.org/10.1016/j.aos.2009.07.006

Sevin, S., \& Schroeder, R. (2005). Earnings management: Evidence from SFAS no. 142 reporting. Managerial Auditing Journal, 20(1), 47-54. http://dx.doi.org/10.1108/02686900510570696

Sullivan, J. D. (1984). The evaluation of internal control and the design of substantive audit tests. Auditing Symposium VII, Lawrence, KS.: University of Kansas. http://dx.doi.org/10.1177/0959354394044004

Svenson, O., \& Edland, A. (1987). Change of preferences under time pressure: Choices and judgments. Scandinavian Journal of Psychology, 29(4), 322-330. http://dx.doi.org/10.1111/j.1467-9450.1987.tb00769.x

Trotman, K. T., Tan, H. C., \& Ang, N. (2011). Fifty-year overview of judgment and decision-making research in accounting. Accounting and Finance, 51(1), 278. http://dx.doi.org/10.1111/j.1467-629X.2010.00398.x

Van Buuren, J., Koch, C., Amerongen, N. V. N., \& Wright, A. M. (2014). The use of business risk audit perspectives by non-big 4 audit firms. Auditing, 33(3), 105. http://dx.doi.org/10.2308/ajpt-50760

Webb, A., Jeffrey, S. A., \& Schulz, A. (2010). Factors affecting goal difficulty and performance when employees select their own performance goals: Evidence from the field. Journal of Management Accounting Research, 22, 209-232. http://dx.doi.org/10.2308/jmar.2010.22.1.209 
Weber, R. (1980). Some Characteristics of the Free Recall of Computer Controls on EDP Auditors. Journal of Accounting Research, Spring (1980), 214-241. http://dx.doi.org/10.2307/2490399

Wright, W. F., \& Berger, L. (2011). Fraudulent management explanations and the impact of alternative presentations of client business evidence. Auditing, 30(2), 153-171. http://dx.doi.org/10.2308/ajpt-50010

Yerkes, R. M., \& Dodson, J. D. (1908). The relation of strength of stimulus to rapidity of habit-formation. Journal of Comparative Neurology and Psychology, 18, 459-482. http://dx.doi.org/10.1037/h0022080

\section{Note}

Note 1. Koonce (1993) provides a 5 step model that includes (1) Mental representation, (2) Hypothesis generation, (3) Information searches, (4) Hypothesis evaluation, and (5) Decision about sequence actions. The model aims to help the auditors to use a linear decision making process when the results of the analytical procedure are suspicious or unexpected.

\section{Copyrights}

Copyright for this article is retained by the author(s), with first publication rights granted to the journal.

This is an open-access article distributed under the terms and conditions of the Creative Commons Attribution license (http://creativecommons.org/licenses/by/3.0/). 